the Library where objects could be seen to illustrate books on the Library's shelves. In 1872, when the new Library wing was opened, the Museum was housed in the basement beneath it and opened to the public. It has continued to be closely integrated with the Library, and the Library Committeo of the Common Council is directly responsible for its administration. Since 1921 the Museum has been supported financially by the City of London Corporation. All the objects in Guildhall Museum are connected with the City, many of them consisting of archaoological material, including much that has boen unearthed in the course of excavations connected with the re-building of the City since 1946. Guildhall Museum has always been closely associated with the scientific examination of sites cleared for re-building, and it has been generally agreed that all objects found during excavation should be given to the Museum. During the past eighteen years the total number of specimens in the Museum has increased by more than fifty per cent. As a result of war and war-damage the Guildhall collection moved about, and eventually the exhibition, containing about 10 per cent of the collection, carne to rest in the Royal Exchange; most of the collection was left in store at Guildhall.

Like the London Museum, Guildhall Museum is thus still waiting for adequate accommodation in a permanent home. Both are essentially local museums, although the London Museum obviously has a far more than local interest. From this situation arose the idea that the accommodation problem might be solved by bringing the two Museums together under one roof with the cost shared between the Treasury and the County Counoil and the City of London. The essence of the scheme is that the two Museums will be amalgamated to form a new Museum of London, housed in a new building to be erected for the purpose on a site in the City of London. The capital and running costs will be borne jointly and equally by the Exchequer, the City Corporation and the Greater London Council, which has agreed to accept the obligations entered into by the London County Council in respect of the project. The Museum will be managed by a board of eighteen governors, six being nominated by each of the throe authorities. An Interim Board of Governors was constituted on these lines in May 1962, and a Director and Deputy-director-designate were appointed and a firm of architects was invited to prepare a preliminary scheme and estimates. This scheme provides for the Museum building to be on six floors, arranged around a garden court, with its east side forming the base for a 200 -ft. high office tower block which will be leased separately by the City Corporation and will be so arranged that some 19,000 sq. ft. of space can be made available for expansion of the Museum at a future date. The Bill provides for payment by the Treasury of a sum not exceeding $£ 150,000$ in respect to furniture and equipment, and for the staff of the Museum to be brought within the Corporation's superannuation scheme. Staff salaries will be determined by the Corporation after consultation with the Treasury and the Greater London Council.

\title{
THE BATTELLE INSTITUTE, GENEVA
}

NDEPENDENT consultative and sponsored research
in industry has long been established practice in
the United States, perhaps more often than not on a
commercial rather than a strictly professional seale, as
has been the general tendeney over the years in Britain,
although to this latter traditional precept there are
to-day some noteworthy exceptions successfully estabto-day some not
lished in Britain.

The original aim of the founder of 'Battelle', Gordon Battelle (Battelle Memorial Institute, Columbus, Ohio), was ". . to contribute to industrial development by disseminating and using scientific knowledge for purposes of discovery and invention, thereby furthering technical progress". Battello now has three research centres, at Columbus, Frankfurt and Geneva, with six branch offices in Washington, Los Angeles, Paris, London, Madrid and Gothenburg. It has thus established active and regular relations with industrial and scientific centres, as well as Government authorities throughout the western world; its activities are spreading to some of the so-called developing countries.

A booklet entitled Ten Years' Research at the Battelle Institute, Geneva*, has recently been published, marking the completion of ten years' work of this organization in Geneva; it presents a well-documented and illustrated picture of some of the many and varied activities of the

*Ten Years' Research at the Battelle Institute, Geneva. Pp. 71. (Geneva: Battelle Institute, 1964.) Copies are also obtainable from the Battelle Institute, Ltd., 15 Hanover Square, London, W.1.
Institute at this particular centre. It is described as "... an invitation to European industry to visit the Institute". The impact of this well-designed and profusely illustrated publication can scarcely fail to impress the reader with the scale on which the Institute operates not only at Geneva but also internationally. A selection of some of the important disciplines covered by this centre includes: economics; applied mathematics; semi-conductors (solid-state physics); electronic paramagnetic resonance; optics; ultra high-vacua; metallurgy and physical properties of materials; refractory ceramic materials; electrochomistry; physical processes of measurement and analysis; electrical engineering and electronics; mochanical engineering; industrial high polymers and petrochemistry; foodstuffs; pharmaceutical and phytopharmaceutical products; chemical engineering; and mathematics and theoretical physies. In connexion with some of these subjeots there have resulted ". . a total of 252 inventions" in the past few years at Geneva, ". . . and 1,266 patent applications have been filed in different countries; 587 patents have so far been issued, 221 of them in countries where prior patentability studies are carried out".

The booklet includes 192 references to publications with which the work and staff of the Institute have been concerned in the course of the research projects referred to here. For obvious reasons much sponsored research is of necessity highly confidential as between client and the Institute: to this extent the full story of achievements of the Institute cannot be divulged.

\section{COSMOLOGY IN THE U.S.S.R.}

T HIS account summarizes articles which have appeared in Priroda. A. G. Nikolaev and P. R. Popovich $(1,1 ; 1963)$ provide photographs of the Earth's surface as seen from a sputnik. G. A. Skuridin $(1,3 ; 1963)$ discusses cosmic physics-the radiation belt of the Earth, interplanetary plasma, primary cosmic radiation, magnetic fields of the Earth and the Moon and short-wave solar radiation. V. V. Shuleikin $(4,53 ; 1964)$ gives an account 